\title{
ACBAR
}

\section{Compilation of the}

\section{WOMEN}

Sub-committee documentation

$$
\begin{gathered}
1994 \\
\text { to } \\
1997
\end{gathered}
$$

Agency Coordinating Body for Afghan Relief

2 Rehman Baba Road

U.P.O Box 1084

University Town

Peshawar, NWFP

Pakistan

TEL: 091 44392/40839

FAX:091-91-840471

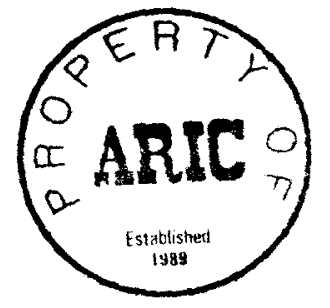

EMAIL: acbaaroradio.psh.net pk 


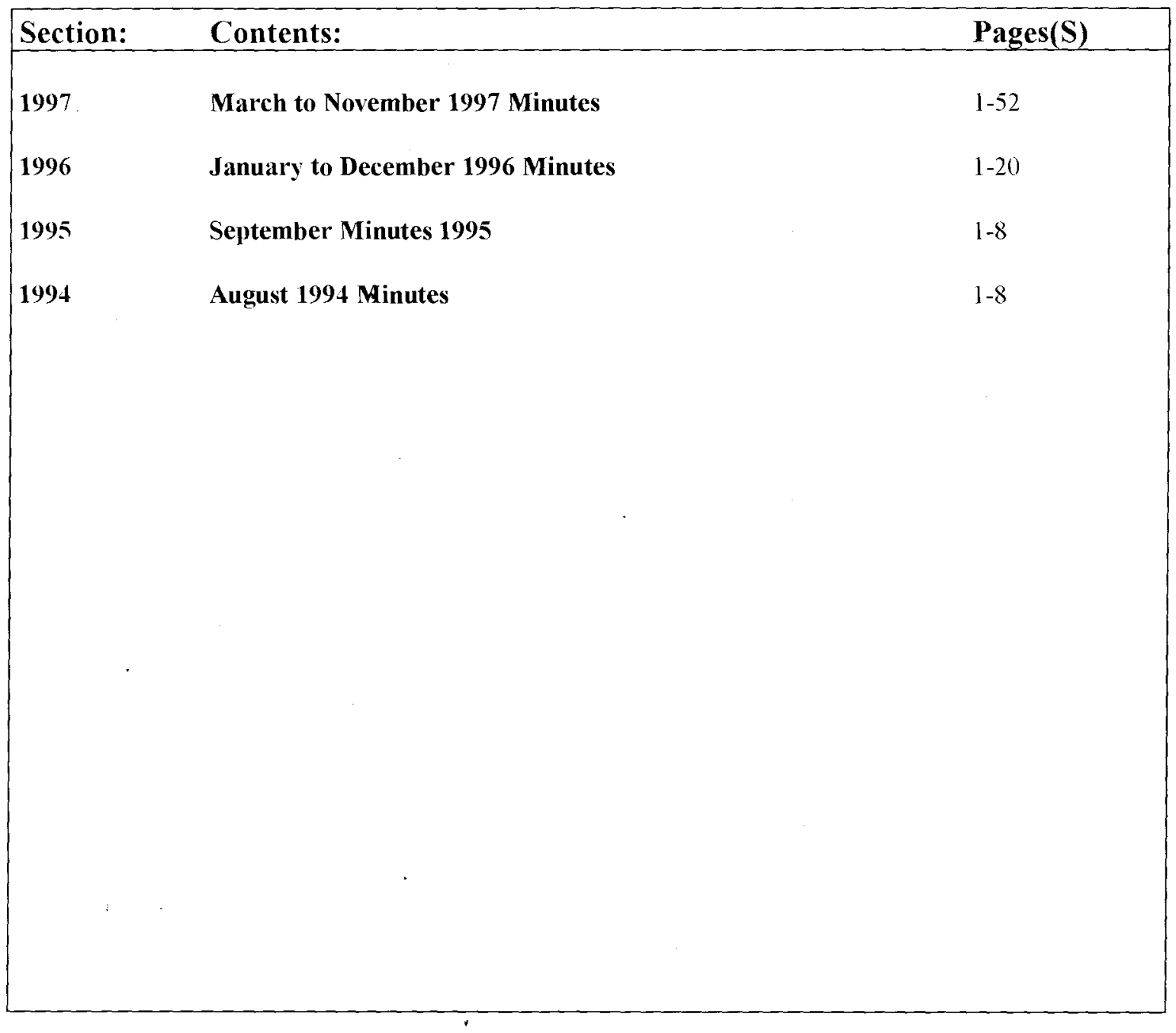




\section{Women's Affairs Meeting}

March 11, 1997

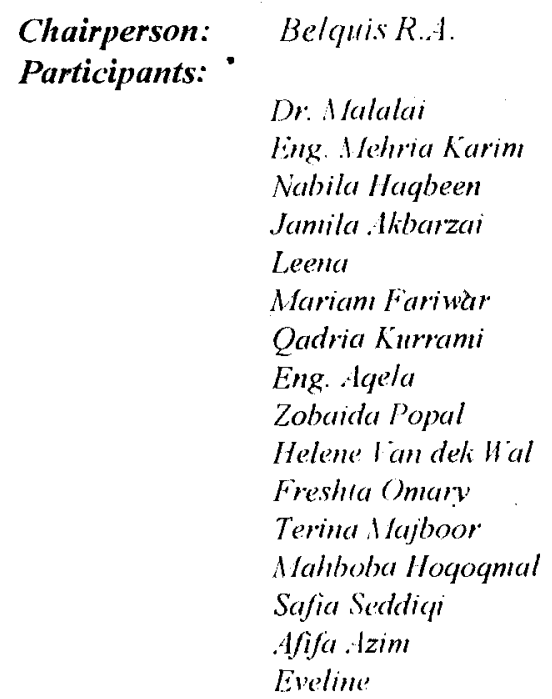

$A C B A R$

$S C A$

$A T C$

FEW

$A W W D$

NC.A

Afghanaid

NPORRAA

$A W D P$

$D C A$

$D C A$

$C C A$

CCA

ANIRAN

D. $.1 C: H A R$

Radda Bamen

INOC $M$

Apologies:

Khorshid
Razia \& Sharifa

NAC (busy in a siminar)

DACALR (had a training course).

Approval of the agenda and minutes of the last meeting

The Chairperson apologizcd for the error in the agenda about date of the meeting. Minutes of the last meeting were approved.

\section{Finalisation of the newsletter}

Eng. Aqela, AWDP. had prepared a draft of symbol for the newsletter. However. after a prolonged discussion. it was suggested that an artist be contacted to finalize designing the sumbol.

Contents of the first issue of the newsletter. which is going to be printed by the end of March. will be as follow:

- An introduction article about the Afghan Women Network. its aim and date of establishment. What has been achieved so far would also be included in the contents of the first issue.

The various contents of the newslefter will be in Dari and Pashtu languages. An English summary of contents will also be included.

The aim of publishing the newsletter is to spread information about women's activities. problems and needs enhanced by members of the Network for other members. NGOs. UN agencies. Donors. etc. 
Ms. Safia Seddiqi will try to contact an artist regarding the symbol.

Ms. Eveline. UNOCHA. would check if UNOCHA could provide assistance in spreading the information through their E-mail system. to other women organizations in the world and donor communities.

CCA will assist in computerizing the newsletter while NCA agreed to cooperate in making copies for circulation.

\section{Reports from the working groups}

\section{a) Cultural working group:}

Eng. Aqela was thanked for the valuable time she had spent on preparing the symbol of the network. The Cultural working group has, not been able to do more because of poor participation of members. The members were requested to regularize their attendance.

\section{b) Health working group:}

DACAAR' training project has been busy training some 14 women (as health cducators) from Herat and Nangarhar provinces of Afghanistan. The course continued for two weeks.

Dr. Zobaida. DCA. reported the following matters from her witnesses during her visit to Arab and Janikhil refugee camps.

* Arabs Refugec Camp:

Pcople have problems in getting potable water. There are only two wells. dug by DACAAR water supply project. Women s health situation was described to be poor. which is mainly because of the cultural restrictions on taking the women out of the camp for treatment. The population of the camp) is roughly estimated to be more than 1000 families.

\section{* Janikhil Camp:}

This is not a new camp. but the situation of. specially. women's health is very poor as similar to Arabs camp. There have been no vaccination teams for vaccinating mothers and children. On the other hand, the inhabitants of the camp who are mostly Kochis. have no interest in vaccinating their children. Population of the camp was said to be around 500 families.

Taking account of the situation reported above. the floor suggested some projects to be undertaken in the camps, i.e. digging new wells. establishing health centers. running income generating projects to assist the people's economy, etc. It was also suggested that summary of the problems be forwarded to UNHCR to provide relief assistance to the people.

\section{c) Foreign Relations working.group:}

Nothing particular has becn done so far.

It was stated that expatriate female staff of aid agencies can become members of this working group.

\section{d) Social Affairs:}

Radda Bernen has started a one year anemation training program for 20 women including $2 \mathrm{new}$ refugee women. The program contains training in child's right. women's right. community mobilization. gender issue. rehabilitation and some other tasks.

Radda Bernen also reported tha!. lately, people in Nasir Bagh camp have established a school for 700 students. It was added that there are volunteers from the camp who teach in this school.

It was suggested that the network members donate some assistance to the needy new refugees. They can contribute in cash or kind i.e. cloths. and other materials. The donations could be distributed by the Radda Bernan's trained social workers. This suggestion was warmly welcomed by all the participants. 


\section{Database of women related activitics}

ACBAR's women Sub-committec is planning to produce a database for women related activitics of agencies. The participants were briefed on how to fill the forms which will be send to the NGOs in the near future.

\section{Any other business}

The Chairperson emphasized on the importance of attending the meetings regularly. and being on time for the meetings.

This norm was once again stressed upon that those members who miss three consecutive meetings without valid reasons and/or apologies will be dropped from the mailing list of the Women Affairs meeting.

\section{Next meeting}

The next meeting will be held on Wednesday 9 April 1997 at 10:00 am, in ACBAR Conference room.

The following people have not attended several consecutive meetings of the Women Affairs and have shown little involvement in their relevant working groups activities. so their positions within their working groups have been replaced:

1. Aziza Azizi. AWRC. from Cultural Working Group (WG):

2. Massoda- AGHCO. Nasrin-VSB. Sofia- AWRC. Shahla- CCA from Social Affairs WG:

Attached pleașe find a copy of the updated list of members of the various working groups. 
Cultural

\begin{tabular}{|l|l|l|l|}
\hline SN & Name & Agency & Phonc \\
\hline 1 & Mahboba Hoqoqmal & AMRAN & 845446 \\
\hline 2 & Noorzia & CoAR & 41188 \\
\hline 3 & Safia & DACAAR & 43245 \\
\hline 4 & Khorshid Noori & NAC & 43717 \\
\hline 5 & Fawzia & AWC & 812115 \\
\hline 6 & Leena & NCA & 840304 \\
\hline 7 & Jamila Akbarzai & AWWD & 843497 \\
\hline 8 & Partawmina & AWRC & $\mathbf{8 4 1 5 5 2}$ \\
\hline
\end{tabular}

\section{Health}

\begin{tabular}{|l|l|l|l|}
\hline SN & Name & Agency & Phone \\
\hline 1 & Dr. Zobaida & DCA & 44731 \\
\hline 2 & Dr. Shamshad & DCA & 44731 \\
\hline 3 & Dr. Malalai & SCA & 814772 \\
\hline 4 & Razia & DACAAR & 40731 \\
\hline 5 & Sharifa & DACAAR & 40731 \\
\hline 6 & Dr. Noorjan & AWRC & 841452 \\
\hline
\end{tabular}

Foreign relations

\begin{tabular}{|l|l|l|l|}
\hline SN & Name & Agency & Phonc \\
\hline 1 & Mehria & ATC & 40412 \\
\hline 2 & Safia & DACAAR & 43245 \\
\hline 3 & Belquis & ACBAR & $44392 / 40839$ \\
\hline 4 & Mahboba Hoqoqmal & AMRAN & 845446 \\
\hline 5 & Rahela & WFP & 273641 \\
\hline 6 & Farida & NCA & $\mathbf{8 4 0 3 4 0}$ \\
\hline
\end{tabular}

Social Affairs

\begin{tabular}{|l|l|l|l|}
\hline SN & Name: & Agency & Phone \\
\hline 1 & Fariha & NPO/RRAA & 41129 \\
\hline 2 & Sohaila & SOS-PG & 812456 \\
\hline 3 & Amena Bower & MARUF & 44986 \\
\hline 4 & Eng. Aqela & AWDP & \\
\hline 5 & Qadria & NPO/RRAA & \\
\hline 6 & Malalai & ACDC & \\
\hline 7 & Freshta & CCA & 810116 \\
\hline 8 & Terina & CCA & 810116 \\
\hline 9 & Afifa & Radda Bernen T/U & 43905 \\
\hline
\end{tabular}




\section{ACBAR

\section{Women Affairs Sub-committee Meeting April 9, 1997}

Chairperson:

Partawmina

Minutes:

Belquis R.A.

Participants:

Eng. Mehria

Spozhmai

Eng. Aqela

Jamila Akbarzai

Masooma

Jamila

Freshta Omary

Noorzia

Safia Seddiqi

Noorjan

Faralunaz.

Dr. Zobaida

Rahima

Nabila

Leena

Nazifa

Homa Zafer

Apologies:

Jamila Aman
$.111 R C^{\circ}$

ACBAR

ATC

AWC

AWDP

AWWD

Bibi Sarwari School

Nazoana School

CCA

COAR

DACAAR

DACAAR

DACAAR

DCA

FEW

FEW

NCA

Malalai School

Khaharan Magazine

Farida

Dr. Samia

Farida

Sadozai

Eng. Rahela

Sohaila

Nasrin

Afifa

Fariha

Khorshid Noori

Zohra Kakar

Mariam Kakar

Homaira

Evelin

GTZ-NSP

UNOCHA

Belquis Baluch

ROAOW

Agenda:

- Approval of the agenda and minutes of the last meeting

- Update on Gender Advisory Group (GAG) achievements (by Safia)

- Reports from the working groups" activitics

- Presentation of AWAI (by Ms. Kakar)

- Any other business

\section{Approval of the agenda and minutes of the last meeting}

Report on meeting with Mr. Bruderlcin, was included in the agenda. The meeting. therefore. was called an hour earlier than the schcduled time. Minutes of the last meeting were approved.

\section{Report on the meeting with Mr. Bruderlien}

ACBAR briefed the floor on the meeting which was organized and hosted by CCA in Peshawar on 4 April 1997. Mr. Bruderlien. Department for Humanitarian Assistance (DHA). Policy Advisor has come from New York on a visit to Pakistan and Afghanistan. He has stated his purpose of visit to be meeting with - Afghans and seek their constructive opinions on restoration of peace in Afghanistan. Mr. Bruderlien. in the meeting, requested the Afghan women for their ideas and solid suggestions to be followed up by UN. 
The Women Sub-commitlec decided to preparc a statement for the UN Representative. which will contain suggestions relating 10 different fields. Part of the contents of the statement were worked out in mecting as follow:

* Members of the sub-committee are concerned to understand the real interest of UN to follow up the suggestions.

1. UN should continue providing education for boys even if the girls' education is denied in Afghanistan. Afghans do not want to have an entirely un-educated generation.

2. UN should give priority to supporting formal and non-formal cducational services for refugecs in Pakistan and Iran.

3. Income gencrating projects should be supported which will help create jobs for Afghans inside Afghanistan or in Pakistan. This will provide a ground for peace support.

4. UN should support women related activities permitted by Taliban.

5. UN programs for Afghanistan should give priority for employment of Afghans than Pakistanis

\section{Presentation of AWAI}

Ms. Mariam Kakar. member of the Afghan Women's Association International in San Diego (AWAI). has recently come to Pakistan from San Diego. USA. where AWAl is based. She bricfed the participants on her organization and its objectives. AWAI has becn formed by a number of Afglan individuals who aim to provide possible assistance for Afglianistan. Similar associations have also becn cstablishicd in Catifornia and Los Angles. She added the purpose of her travel to Pakistan and Afghanistan to be collecting information on. specially. cducation situation. She welcomed proposals for assistance.

The Pakistan based refugec schools can submit proposals to "Belquis R. A. in ACBAR Peshawar".

\section{"Publishing House" for Afghan women}

In a meeting in Islamabad. Ms. Nancy Dupree had suggested that there was a necd for establislment of a publishing house for Afghan women. It was expressed that the voice of Afghan women should be reflected world-wide.

As a follow up of Nancy's suggestion. the Women Sub-committee decided to develop a proposal for establishment of a publishing house to be submitted to some donors. It was decided that a meeting be arranged to discuss, particularly. this and some other issues. The meeting was decided to take place at 11:00 am on 12 April 1997 in WFP office. The issues to be discussed were listed as follow:

* Afghan women in Peace process: .

* Establishment of publishing house for Afghan women;

* Conducting workshops and training courses for the NGOs staff; and

* Goals and Objectives of AWN.

\section{Any other business}

There was no other business. The meeting was. therefore. adjourned.

The next regular meeting of ACBAR Women Sub-committee will be held at 10:00 am on 29 Ajril in ACBAR office.

The proposed agenda includes:

- Formation of AWN Executive Board 10:15-11:15

- Activity update

$11: 15-11: 45$

- Any other business

i1:45-12:00

Note: Please bring your monthly one page activity report to the meeting. 


\section{Women Affairs Sub-committee Meeting 10:00 am May 13, 1997}

Chuirperson: Belquis R.A.

Participants:

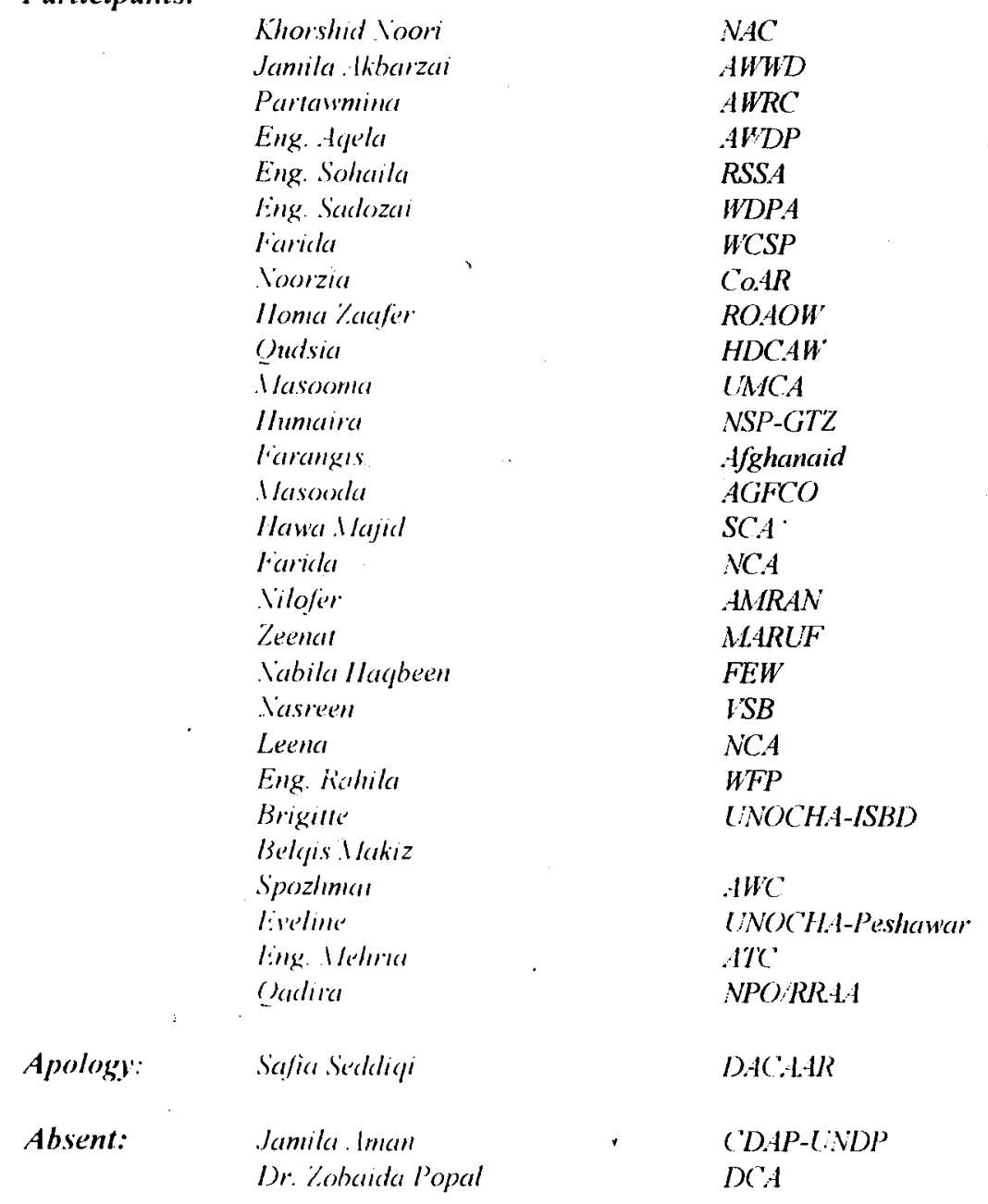

$A C B A R$

Agenda:

- Approval of the agenda and minutes of the last meeting

- Announcements

- Formation of AWN Executive Committee

Approval of the agenda and minutes of the last meeting

Both the agenda and minutes were approved.

Announcements

NCA and ACBAR intend to conduct a workshop on Networking on 21 May 1997. The workshop will be facilitated by Mohammad Ehsan from NCA and Jawed Ludin from ACBAR. Venue of the " orkshop will be ACBAR conference room. Invitations for the participants will be circulated later. 
Formation of Afghan Women Network (AWN) Exccutive Committec

Group work: Discussions on the following topics took place in three groups. Each topic discussed for 20 minutes.

1. Is cxistence of AWN in Peshawar needed?

2. Suggcstions for the improvement of the AWN

Here are some of the ideas that came out of the group discussions:

For the first topic

Existence of AWN is highly necded:

For the second topic

- $\quad$ executive committee be formed:

- unity and cooperation between the members of the network be cncouraged:

- $\quad$ male colleagues be invited in meetings when their consultation is nceded:

- $\quad$ job descriptions for the members be developed:

- $\quad$ achicvements of the Network be reported on a regular basis:

- $\quad$ the four already cstablished committees be reorganized:

- $\quad$ regular workshops be conduct for agencies`stafr

Brigitte Neubacher from UNOCHA Islamabad bricfed the floor on objectives of the Resource Center for gender and Women's Human Rights in Afghanistan.

The Resource Center has recently been established with the aim to:

- $\quad$ increase coopcration among agencics. NGOs and donors on gender issucs and human rights.

provide training for UN agencies. NGOs. donors and Afghan communities regarding gender and human rights perspective.

- $\quad$ research on gender issues and human rights.

The contact person for the Resource Center is Latifa Irshad. coordinator resource center.

The Chairperson requested volunteers for membership of the Executive Committec to introducc themselves and explain if they have experience in gender related ficlds.

The following person were elected as members of the Executive Committce:

\begin{tabular}{|l|l|}
\hline \multicolumn{1}{|c|}{ Name } & \multicolumn{1}{c|}{ Title } \\
\hline Eng. Rahcla Harecr & Coordinator \\
\hline Khorshid Noori & Member \\
\hline Hawa Majid & Member \\
\hline Jamila Akbarzai & Member \\
\hline Homa Zaafer & Member \\
\hline Belquis R.A & Member \\
\hline Partawmina & Member \\
\hline
\end{tabular}

Any other business:

Participants were asked for financial contribution for the Network. A form was circulated to the floor to write the amount of contribution before their names. The money would be used for the expenses of the Network ie logo, etc.

Next meeting: will be held on Tuesday 17 June 1997 at 10:00 am in ACBAR

conference room. Attached please find the agenda for the ncxt meeting. 


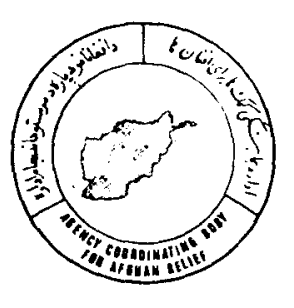

\section{Women Affairs Sub- Committee Meeting \\ 10:00 am, 17June 1997}

Chairperson:

Belquis R.A

ACBAR

Participants:

$\begin{array}{ll}\text { Aziza } & \text { IRC/WELP } \\ \text { Diana } & \text { ANCB } \\ \text { Dr.Zubida } & \text { DCA } \\ \text { Eng.Aqila } & \text { AWDP } \\ \text { Eveline } & \text { UNOCHA } \\ \text { Farangis } & \text { Afghanaid } \\ \text { Farida } & \text { NCA } \\ \text { Ferashta Omari } & \text { CCA } \\ \text { Hawa Majid } & \text { SCA } \\ \text { Homa Zaafer } & \text { ROAOW } \\ \text { Jamila Akbarzai } & \text { AWWD } \\ \text { Diana Poya } & \text { ACBAR }\end{array}$

Lema

Leena

Masooda

Masuma

Nabilla Haqbeen

Nelofar

Noorzia

Partawmina Hashemi

Qadria

Qudsia

Shahida

Sohaila
AWDA

NCA

AGHCO

AWDH

FEW

AMRAN

COAR

AWRC

NPO/RRA

ADCAW

DACAR

S.A Belgium

Apologies:

$\begin{array}{ll}\text { Safia Seddiqi } & \text { DACAR } \\ \text { khorshid Noori } & \text { NAC } \\ \text { Afifa Azim } & \text { RB/TU } \\ \text { Eng. Rahila } & \text { WFP-ISBD }\end{array}$

Approval of the agenda and minutes of the last meeting;

Both the agenda and minutes were approved.

Announcements;

AWN together with ACBAR intend to conduct a workshop on communication on 1 July 1997. The workshop will be facilitated by Sediqa from RB/TU. Co-facilitators will be Farangis from Afghanaid and Qudsia from AWWD. The workshop will take place in ACBAR office.

Update on AWN activities;

Ms Partawmina on behalf of executive committee of AWN briefed the participants on activities undertaken during the last month. She added that the members of executive committee meet every week to make preparations for workshops and other activities such as writing proposals, organizing meetings with heads of agencies etc.

- $\quad$ the newsletter is finalized, (copy attached)

- a draft proposal has been prepared

- due to financial problems, we have not been able to prepare a letter head for $A W N$, however it will be printed within 10 days.

- for official recognition of AWN, a letter addressed to head of agencies will be distributed soon. 
regarding the workshops the executive members felt that other members of AWN should prioritize the topics for the workshops to be undertaken in the year 1997. Therefore a list of workshops was written on the board and participants were requested to work in groups and prioritize the topics.

The following was the result :

1. Communication

2. Gender awareness

3. Women's human/Islamic right

4. Conflict resolution

5. Report writing

6. Management/record keeping

7. Leadership

8. Proposal writing

9. Human right

10 Child right

11. Decision making

12. Women and development

The executive committee of the Network will make preparations for organizing the above listed workshops.

\section{Women database;}

ACBAR briefed the floor on the information collected so far. Those agencies who have not received the forms were asked to contact Belquis.

Participants expressed their feelings on serious need for such information.

\section{Chairperson \& date for the next meeting;}

Ms. Homa Zaafer was appointed as chairperson for the next meeting which will be held on 17 July 1997.

\section{Any other business;}

For reorganizing the working groups, AWN "members' application" forms wcre circulated to be filled by the participants during the tea break. The forms were collected at the end of the meeting.

- $\quad$ ACBAR mailing list of women affairs sub-committee was circulated to the participants to make sure that their addresses are correct. Recently some NGOs had complained that they do not receive the minutes and agenda on time.

- The financial contribution form was also circulated and members' werc asked for contribution.

- Some participants felt that from now on male colleagues be invited in the meetings. The final decision was left to be discussed laater. 


\section{Women Affairs Sub- Committee Meeting 10:00 am, 17.July 1997}

$\begin{array}{lll}\text { Chairperson: } & \text { Homa Zaafer } & \text { ROAOW } \\ \text { Minutes: } & \text { Belquis } & \text { ACBAR }\end{array}$

Participants:

$\begin{array}{ll}\text { Aziza } & \text { WELP } \\ \text { Diana lbrahimi } & \text { ANCB } \\ \text { Dr. Zubaida } & \text { DCA } \\ \text { Eng. Aqila } & \text { AWDP } \\ \text { Khorshid Noori } & \text { NAC } \\ \text { Farangis } & \text { Afghanaid } \\ \text { Nasima } & \\ \text { Ferashta Omari } & \text { CCA } \\ \text { Fukhraj } & \text { Afghanaid } \\ \text { Homa Zaafer } & \text { ROAOW } \\ \text { Jamila Akbarzai } & \text { AWWD } \\ \text { Lema } & \text { AWDA } \\ \text { Diana Poya } & \text { ACBAR } \\ \text { Randall B. Olson } & \text { American Consulate } \\ \text { Hamida Anwari } & \text { ICC } \\ \text { Palwasha Hassan } & \text { NBSD/ICC }\end{array}$

\section{Chief Guest:}

Ustad Danish Zaringar

$\begin{array}{ll}\text { Qudsia } & \text { HDCAW } \\ \text { Masooda } & \text { AGHCO } \\ \text { Zarghuna } & \text { MARUF } \\ \text { Nasreen } & \text { VSB } \\ \text { Nelofar } & \text { AMRAN } \\ \text { Noorzia } & \text { CoAR } \\ \text { Fawzia } & \text { CARE } \\ \text { Qadria } & \text { NPO/RRA } \\ \text { Nooria } & \\ \text { Sohaila } & \text { BEFARe } \\ \text { Sohaila } & \text { S.A Belgium } \\ \text { Lng. Mehria } & \text { ATC } \\ \text { Masoma } & \text { AWDA } \\ \text { Siame } & \\ \text { Brishna Mangal } & \text { HWAD }\end{array}$

Approval of the agenda and minutes of the last meeting;

Both the agenda and minutes were approved.

\section{Announcements;}

(a) AWN together with ACBAR intend to conduct a workshop on Gender Awareness on 31 July 1997. The aim of the workshop is "to raise awareness on gender issues in Afghanistan; to discuss gender terminology and to encourage advocacy on gender."

(b) Pro Software Development (PSD) is an Afghan computer training course located in University Town. The course is planning to commence four weeks training course for men and women on the following topics:

- Electronic Data Processing

- Configuring your PC

- Trouble Shooting

For more information, please contact phone number 41377. 


\section{Update on AWN activities;}

Ms Khorshid Noori on behalf of the Executive Committee of AWN briefed the participants on activities undertaken during the last month. The activities are summarized as follow:

* Collecting material for the workshops on communication and gender awareness, and organizing the communication workshop,

* a proposal for funding the workshops has been submitted to donor agencies.

* AWN was officially introduced to heads of agencies at the ACBAR General Assembly.

* directors of NGOs were requested through an official letter to designate a female staff of their organization to participate in AWN meetings and take active role in improving the network.

* the executive committee is working on preparing rules and regulations for AWN. Ideas from members would be included.

\section{Review of Communication workshop}

Ms. Farangis presented a summary of the workshop results. The participants also shared their learning from the workshop. The main topics covered by the workshop were "communication", "meetings" and "interviews".

Chairperson \& date for the next meeting;

Ms. Hamida Anwari , ICC, was appointed as chairperson for the next meeting, which will be held on 18 August 1997 at the ACBAR office.

\section{Any other business;}

A Mr. Randall B. Olson from US Consulate in Peshawar participated in the meeting. He said his purpose for attending the 'meeting was to get an idea of Afghan women's living conditions and problems, particularly those of refugees. Mr. Oslon noted the problens presented by participants. The main problems were presented by Ms Zaringar.

B Ms. Danish Zaringar, an Afghan poetess and artist, briefed the floor on problems of refugees in Nasir Bagh Camp. Lack of drinking water and food supplies have worsened the living conditions of refugees in the camp. Women are usually not well respected, particularly by aid workers. It was added that security situation in the camp has also deteriorated and there are a lot of shooting at nights . The refugees face a shortage of health and education facilities. There is a visible increase in cases of skin diseases as well as Rabies in the camp. On the distribution of rations, it was said that the number of family. members is not considered at time of distribution. She requested representatives of the Sub-committee to visit the camp and see the living conditions of the refugees.

\section{Suggestions:}

- Afghan should be given priority in employment in aid agencies;

- Afghan personnel should accompany each survey teams to discuss with people in their oun language:

- ACR-AR should write a letter to the NGOs working for retugees in lisir Bash Camp. and see $\therefore \because \cdots \cdots \cdots \cdots \cdots \cdots$

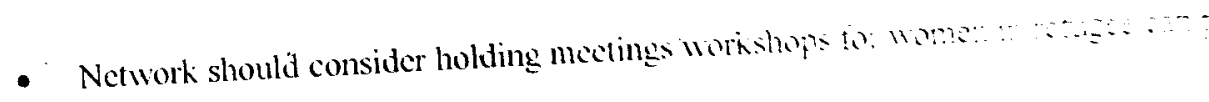


- Members of the network personally contribute money and goods to the refugees;

- It is highly suggested that members should meet with women in the camps and transfer their problems to higher authorities;

- Gender awareness workshop should be provided for refugees women;

- Job opportunities should be provided for refugees women;

- An umbrella of the female NGOs should be formed under the guidance of one of the NGO Coordinating Bodies. This idea needs further discussions.

It was also suggested that :

- Identification card should be provided for members of AWN.

- Male individuals should attend women sub-committee meeting. 


\section{Women Affairs Sub- Committee Meeting 10:00 am, 18 August 1997}

Chairperson: Hamida Anwari IClC

Participants:

$\begin{array}{ll}\text { Farida } & \text { WCSP } \\ \text { Diana Ibrahimi } & \text { ANCB } \\ \text { Khorshid Noori } & \text { NAC } \\ \text { Farangis } & \text { Afghanaid } \\ \text { Ferashta Omari } & \text { CCA } \\ \text { Homa Zaafer } & \text { ROAOW } \\ \text { Jamila Akbarzai } & \text { AWWD } \\ \text { Lema } & \text { AWDA } \\ \text { Masooda } & \text { AGHCO } \\ \text { Zarghuna } & \text { MARUF } \\ \text { Nasreen } & \text { VSB } \\ \text { Nelofar } & \text { AMRAN } \\ \text { Zakia Wardak } & \text { CoAR } \\ \text { Wahida } & \text { HRA }\end{array}$

$\begin{array}{ll}\text { Diana Poya } & \text { ACBAR } \\ \text { Masoma } & \text { AWDA } \\ \text { Eng. Mehria } & \text { ATC } \\ \text { Brishna Mangal } & \text { HWAD } \\ \text { Eng Sadozai } & \text { WDPA } \\ \text { Laila Sarahat } & \\ \text { Partawmina } & \text { AWRC } \\ \text { Tahera Ihrari } & \text { CHA } \\ \text { Fatana Arifi } & \text { GMM-FAI } \\ \text { Nelofar } & \text { AMRAN } \\ \text { Nabila } & \text { FEW } \\ \text { Farida } & \text { NCA } \\ \text { Belquis R.A. } & \text { ACBAR }\end{array}$

Applogies:

$\begin{array}{ll}\text { Eng Aqila } & \text { AWDA } \\ \text { Aziza } & \text { WELP } \\ \text { Sohaila } & \text { S.A. Belgium }\end{array}$

\section{Approval of the agenda and minutes of the last meeting;}

Comments were made on possible material contribution by members of the Sub-committee to the poor refugees in camps. It was said that the participants should have been requested to present their contributions to the meeting.

\section{Announcements;}

(a) A conference on "Know How Conference on the World of Women's Information" will be held in Amsterdam from August 22-26 1998. The conference will approach the visibility and accessibility of women's information from within the local, regional and global frameworks. The interested individuals can obtain applications for participation, and more information from Belquis, ACBAR.

(b) The next workshop of AWN, Women's Islamic Rights, is planned to be held in ANCB office on 30 September 1997. It was explained that since similar workshops will continue to be conducted in future also, only the limited number of members, those who are invited, should participate. Other members will certainly receive a chance for participation in any of the workshops in future. The Executive Committee of the network is looking for someone professional to facilitate the planned workshop. However, the final decision on holding this workshop will be announced at the next meeting. 
(c) Eng. Rahela, WFP, due to increasing official work load, has resigned from her position as Coordinator of AWN, for which she was elected in May 1997. Based on the Executive Committee's decision, Belquis R A, from ACBAR, has taken over the responsibility of network's Coordinator. Belquis has been critically involved in most of the managerial work of the network since November 1996.

(d) AWN's Executive Committee is seeking suitable candidates for a vacant voluntary position of the committee's member. Interested individuals should submit their applications to Belquis R A as soon as possible.

\section{Update on AWN activities;}

Summary of AWN's activities was presented as follow:

* Organizing the Gender awareness workshop;

* meeting with Prof. Paik, on 1 August 1997 (see details under Any other business, 1);

* identity cards prepared for the individual members, with financial contribution from Ms Khorshid, members will later be required to send their personal data and photographs to the Executive Committee for further process;

+ material for the second issue of the newsletter (Nawe Heela) have been prepared; it will soon be published;

+ the Executive Committee is working on preparing rules and regulations for AWN; ideas from the members would be welcomed;

\section{Review of Gender Awareness workshop}

The Chairperson presented a summary of the workshop results. The participants also shared their learning from the workshop. The workshop on Gender Awareness was conducted by AWN in July 1997. The aim was to open hearts and minds to new ways of learning and to increase awareness of gender roles. The main topics covered by the workshop were "Gender terminology, levels of participation, paid and unpaid work".

\section{Chairperson \& date for the next meeting:}

Ms. Jamila Akbarzai from AWWD will chair the next meeting, which will be held on 16 September 1997 at the ACBAR office.

\section{Any other business:}

1. Participants were briefed about the meeting of AWN representatives with the UN Special Raporteur for Human Rights in Afghanistan held on 1 August:

Summary of remarks:

The Afghit women would like to strongly request, firstly the $U N$, to

- consider the problems of Afghan women seriously; and

- try to convince the authorities about women's rights to education and employment, by Muslim intellectuals from other Islamic countries;

and, secondly, the donor communities to

- extend assistance to the field of education for refugees in Pakistan and Iran, by supporting, at least the already established school and education centers, as well as supporting adult education;

- review and adjust their policies in accordance to the needs; and

- support the organizations working for human rights in Afghanistan.

(Copies of the meeting with Prof. Paik were circulated to the participants) 
18 August coincides to the Independence Day of Afghanistan. As a tribute to the independence day, a discussion was raised on the remarkable old days of Afghan history. Some of the discussions are summarized as follow:

"History is a mirror of the past and a lesson for the present."

Treaty of Gundumak (May 1879)

Louis Cavagnari met with Yaqub Khan at Gandumak on May 20,1879, and signed a treaty which removed restrictions on British travel in Afghanistan and placed an envoy at Kabul.

The main points of Gundumak Treaty included: the British would control Afghanistan's foreign affairs; English-born representative would reside in Kabul and other areas under the protection of the Afghans; the Amir ceded Kurram, Pishin, and Sibi to the British, and agreed to the extension of British control to Khyber and Michni Passes; in return for these concessions, the Amir would receive 60,000 pound per year and loose guarantees for assistance in the event of any foreign aggression.

Louis Cavagnari arrived in Kabul in July 1879 (with a small escort), to serve as the British Resident. On 3 September, the pattern of the First Anglo-Afghan War repeated, and Cavagnari was killed by mutinous Afghan soldiers, who had been paid neither by the Afghans nor by the British, and elements of the Kabul population opposed to the presence of the British contingent. General Roberts moved from Kurram. He reached Kabul on 12 October 1879, and , on the same day Yaqub Khan abdicated the throne. He went to India, where he died in exile in 1923. General Robert became Amir in Kabul. He ruled with an iron hand and instituted a reign of terror remembered to this day. But the Afghans once again did not take lightly the occupation of their country by foreigners. Under the leadership of Mushk Alam, Mohammed Jan Khan Wardak, Mir Bacha Khan and others, a large Afghan lashkar moved on Kabul. General Robert was driven form the field in December. From 400 Afghan women supporting the warriors, 83 were killed only in December that year.

At the battle of Maiwand a legendary Pashtoon heroine, Malalai, used her veil as a standard, and encouraged the warriors by shouting the following couplet (landay),

Young love, if you do not fall in the battle of Maiwand,

By God, someone is saving you as a token of shame.

3 Ms. Breshna spoke about the problems of refugees particularly the problems of Nasir Bagh camp in Pakistan and requested that the network raise these problems with the relevant authorities. The problems were summarized as follow:

The refugees who have spent some of their hard-earned money to build their mud houses in the camp, and now their house are destroyed by PDA, wonder why they chose Nasir Bagh for settlement;

- $\quad$ why did not the Pakistan authorities stop the new refugees from building houses in a camp which was meant for the Regi Lalma township?

why did the UNHCR and the NGOS (SNI), go ahead with construction of one-room houses for the refugees on a land which the PDA wanted vacated for its township project?

NOTE: Those interested in contributing material to the poor refugees in camps are kingly requested to bring the material to the next meeting. 


\section{Women Affairs Sub- Committee Meeting 10:00 am, 16 September 1997}

Chairperson: Belquis R.A. ACBAR

Participants:

Hamida Anwari
Diana Ibrahimi
Khorshid Noori
Farangis
Palwasha
Eng. Sohaila
Qudsia
Lema
Masooda
Zarghuna
Nasreen
Nelofar
Sohila
Adela
Dr. Zobaida
Danish Zaringar

Applogies:

Freshta

$\begin{array}{lll}\text { ICC } & \text { Diana Poya } & \text { ACBAR } \\ \text { NAC } & \text { Masoma } & \text { AWDA } \\ \text { Afghanaid } & \text { Lena } & \text { NCA } \\ \text { AWEC } & \text { Brishna Mangal } & \text { HWAD } \\ \text { RSSA } & \text { Eng Sadozai } & \text { WDPA } \\ \text { HDCAW } & \text { Hekmat } & \text { KEP } \\ \text { AWDA } & \text { Eveline } & \text { UNOCHA } \\ \text { AGHCO } & \text { Tahera Ihrari } & \text { CHA } \\ \text { MARUF } & \text { Taiba Sohaila } & \text { BBC } \\ \text { VSB } & \text { Hadia } & \text { UNOCHA } \\ \text { AMRAN } & \text { Nabila } & \text { FEW } \\ \text { BEFARe } & \text { Farida } & \text { NCA } \\ \text { AREA } & \text { Eng. Aqila } & \text { AWDP } \\ \text { DCA } & \text { Hawa Majid } & \text { SCA } \\ \text { Nasir Bagh Camp } & \text { Safia Seddiqi } & \text { DACAAR }\end{array}$

CCA

The Chairperson (Jamila Akbarzai), apologized for not being able to attend the meeting, Belquis presided the meeting.

\section{Approval of the agenda and minutes of the last meeting; \\ Both the agenda and minutes were approved.}

\section{Review of Working With Conflict Workshop}

From 24 August to 5 September, a workshop on Working With Conflict took place in Swat.

Twenty-one participants from different NGOs and UN agencies participated at the workshop. Four members of the AWN participated.

During the workshop, questions were raised as to what causes conflict and what techniques are effective in settlement of conflict and, especially, how different cultures approach conflict.

The workshop focused on concepts, tools and methods for conflict-analysis, conflict-handling and peacebuilding. In order to deal with conflict, it is necessary to analyze its underlying causes and make use of conflict management strategies. The need for expansion of these skills in the wider Afghan community was strongly felt.

The workshop included communication and group work skills as well as conflict handling skills , such as traditional methods (Jirga), mediation, negotiation and trust building. 


\section{Working groups (members, job description)}

Some modifications were made to the structure of the network and the activities to be undertaken. A number of members were nominated to form the Working Groups.

The draft structure of AWN, along with the names of the members of the working groups are attached to the minutes.

\section{Announcements}

1 The Executive Committee of the network announced Ms. Farangis as a new member of the executive committee. She was selected out of four candidates for the vacant position.

2 The executive committee of the network apologized for postponing the "Women's Islamic rights" workshop, planned for 30 September. The reason was described as not being able to find a religious expert to facilitate the workshop. Instead a workshop on "how to handle conflict" will take place in 30 September 1997 in ANCB office for some 25 women. Invitations and the agenda of the workshop will be circulated later.

3 Ms, Eveline from UNOCHA-Peshawar, announced the arrival of an inter-agency UN Mission on 22 September, who will finalize the Strategic Framework for Afghanistan. Eveline suggested a meeting of the members of the network with the mission. Once the mission comes to Peshawar, a meeting will be organized and members informed.

The Strategic Framework is an open ended process which will help the people in crisis and their national and International partners to formulate a vision of their future actions to achieve a sustainable peace.

4 A UN Gender Mission is scheduled to visit Afghanistan at the end of September and beginning of October

5. UNOCHA have some funds available for Emergency Projects, those seeking funds for emergency projects are requested to contact UNOCHA Peshawar for further information and submit their proposals to UNOCHA Islamabad.

6 The Center for Women's Global Leadership is seeking women's ideas from around the world to get a clear vision of a world where all women enjoy their human rights. Women are asked to produce posters, and a list of 50 questions about women's Human Rights, around the theme "Imagine a world where all women enjoy their human rights."

This is to discuss plans for the "1998: Global Campaign for Women's Human Rights" and to solicit your ideas and participation. To celebrate the fifth anniversary of the World Conference on Human Rights and its historic recognition of women's' rights as human rights, the UN Commission on Human Rights will review implementation of the Vienna Declaration and Program of Action. The Center for Women's Global Leadership is calling on women's NGOs to join in a major global campaign in conjunction with the 50th anniversary of the Universal Declaration of Human Rights in 1998.

25 November 1997, has been named as "Solidarity with Afghan women" day, Announced by Palwasha.

7 The material which was collected from the members to be donated to the poor women in Nasir Bagh Camp were distributed to some 57 poor women. 
Chairperson \& date for the next meeting;

Ms. Farangis Fariwar from Afghanaid, will chair the next meeting, which will be held on 15 October 1997 at the ACBAR office.

\section{$\underline{\text { Any other business; }}$}

- Ms Danish Zaringar read a poem of an Afghan woman refugee who was willing to meet with the members of the network, but due to some problems went back to Kabul.

- Safia Seddiqi from DACAAR, announced Malıboba Hoqoqmal's illness, she will soon have an operation. Mahboba Hoqoqmal, the former President of Law faculty in Kabul University and also member of $\Lambda \mathrm{WN}$. is suffering from cardiac problems. Those willing to donate blood (if required) or support her financially are kindly requested to contact Safia at DACAAR or Belquis at ACBAR.

The following members of the network volunteered to assist Maliboba either financially or by donating blood:

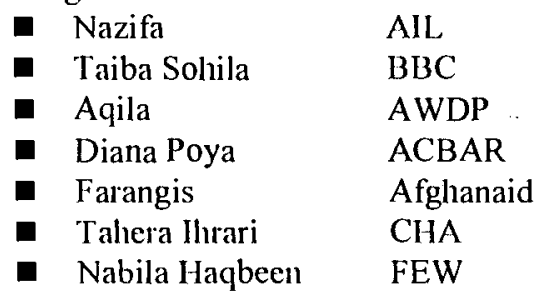

\section{Suggestions:}

It was suggested that $\mathrm{AWN}$ might, in the future, make some funding available for such emergency situations.

It was also suggested by the participants, that in order to support the gender issue and show interest in supporting Afghan women, ACBAR should be asked to allocate a small amount of its membership fee for running cost of AWN activities. It was emphasized that the issue should be raised with the Executive Director of ACBAR as well as with the Steering Committee

NOTE: Those interested in contributing material to the poor refugees in camps are kingly requested to bring the inaterial to the next meeting. 


\section{Working Groups' Members}

\begin{tabular}{|c|c|c|c|c|c|c|}
\hline \multicolumn{2}{|c|}{ Social Affairs } & \multirow[t]{2}{*}{ Training } & \multirow[t]{2}{*}{ Information } & \multicolumn{2}{|c|}{ Human Rights } & \multirow[t]{2}{*}{ Cultural } \\
\hline Health & Educaton & & & Women & Child & \\
\hline Saliha Tawfiq & Fawzia & Farida & Sadozai & Belquis & Afifa Azim & Homa Zaafer. \\
\hline Masooda Omar & Suhaila & Eveline & Jamila Akbarzai & Nasiba & Hekmat & Laila Sarahat \\
\hline Dr. Zobaida & Khorshid & Afifa Azim & Danish Zaringar & 5 & Eng. Aqila & Taiba Sohila \\
\hline Drevasion & Hawa Majid & Belquis & Sohaila (RSSA) & \multicolumn{2}{|c|}{ Palwasha } & Danish Zaringar \\
\hline & Adela & Lena & Eveline & \multicolumn{2}{|c|}{ Masuma } & Aziza \\
\hline & Qudsia & Farangis & Farida (WCSP) & \multicolumn{2}{|c|}{ Tahera Ihrari } & Freshta \\
\hline \multicolumn{2}{|c|}{ Hadia } & Mehria & & \multicolumn{2}{|c|}{ Breshna Mangal } & \\
\hline \multirow{2}{*}{\multicolumn{2}{|c|}{$\frac{\text { Sohaila Yarzad }}{\text { Diana Ibrahimi }}$}} & \begin{tabular}{|l} 
Noorzia \\
\end{tabular} & & \multicolumn{2}{|c|}{ Nabila Haqbeen } & \\
\hline & & Partawmina & & \multicolumn{2}{|c|}{ Sohasila Diana Poya } & \\
\hline \multirow{3}{*}{\multicolumn{2}{|c|}{ Nasrin }} & & $=$ & $\leftarrow$ Ham & a Anwari & \\
\hline & & & & \multicolumn{2}{|c|}{ Zarghuna Azimi } & \\
\hline & & & & \multicolumn{2}{|c|}{ Nazifa Aabedi } & \\
\hline \multirow{2}{*}{\multicolumn{2}{|c|}{ 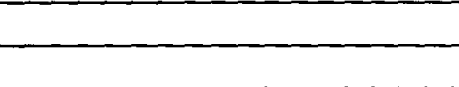 }} & & & \multirow{2}{*}{\multicolumn{2}{|c|}{$+2-2$}} & \\
\hline & & & & & & \\
\hline \multicolumn{7}{|c|}{-} \\
\hline
\end{tabular}


AFGHAN WOMEN NETWORK

AWN

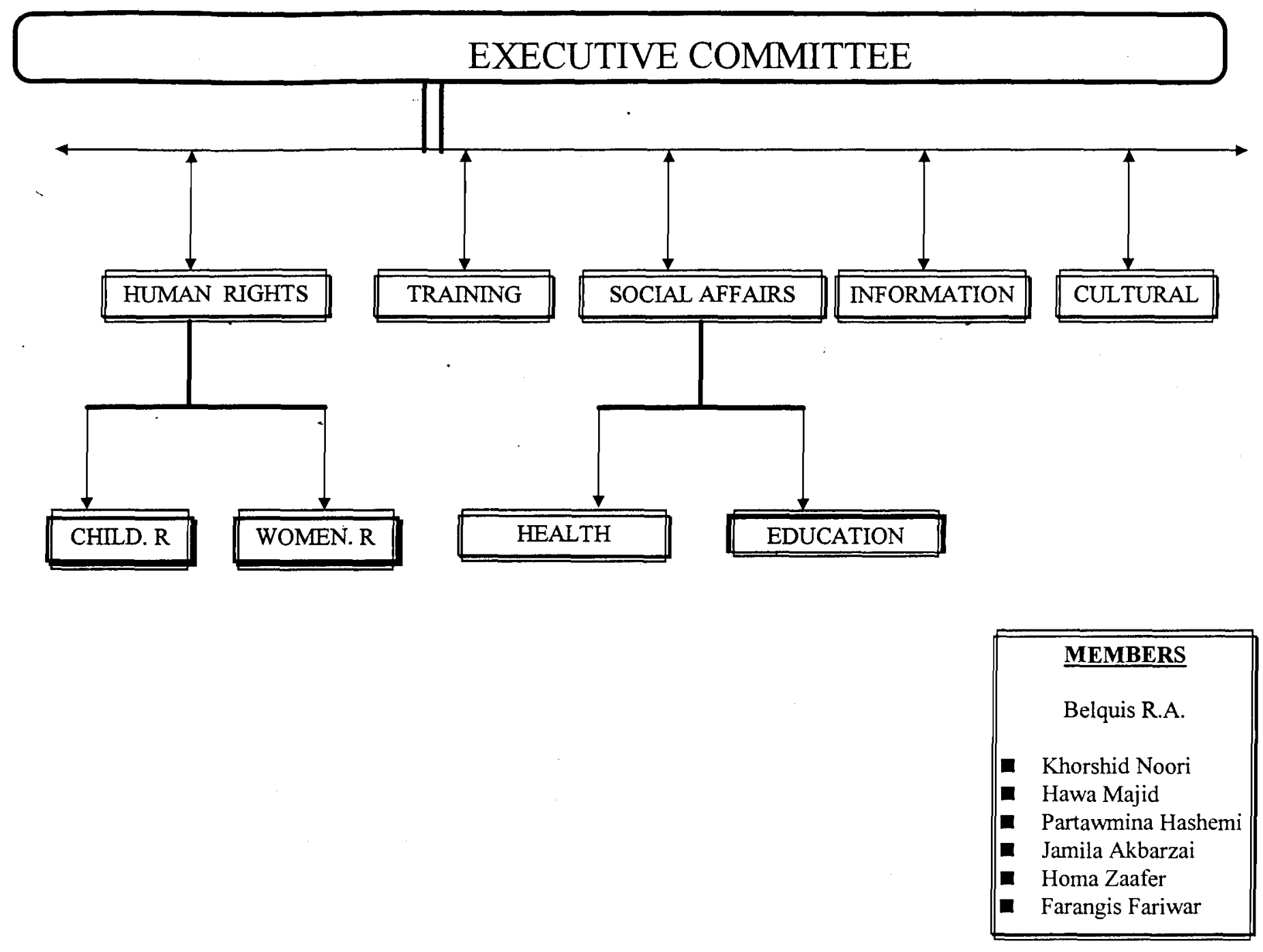




\section{Women Affairs Sub-Committee Meeting 10:00 am, 15 October 1997}

$\begin{array}{lll}\text { Chairperson: } & \text { Farangis } & \text { Afghanaid } \\ \text { Minutes: } & \text { Diana Poya } & \text { ACBAR }\end{array}$

\section{Participants:}

Lema

Khorshid Noori

Sohaila Yarzad

Freshta

Leena

Hadia

Sohaila

Adela

Fawzia

Nasreen

Shaista

Homa Zaafer

Danesh Zaringer

Apologies:

Belquis R.A

Aziza

AWDA

NAC

$S$ A Belguim

CCA

NCA

UNOCHA

RSSA

AREA

CARE

VSB

Naser Bagh Camp

ROAOW

Nasir Bagh Camp

Jamila

AWWD

Farahnaz

UNOPS

Noorzia

Eng Aqela

AWDA

Afifa Azim

RBTU

Eng Mehria

ATC

Dr Nasrin

Shahida

Zarghoona

Fatana Arifi

Dr Zobaida

Ofelia Bornay

Nilofar

$\mathrm{HCI}$

DACAAR

MARUF

GMMFAI

DCA

WFP

UNICEF

\section{Approval of the agenda and minutes of the last meeting:}

Both the agenda and minutes of the last meeting were approved without any comments.

The Chairperson opened the meeting by welcoming the participants. A round introduction took place.

Khorshid Noori, NAC circulated 'name tags' prepared by the Executive Committee of AWN and ACBAR, Women Affairs Sub-Committee, and explained it was meant to be put on during the meeting.

\section{Review of the working with conflict workshop:}

Although the workshóp was said to be very useful and practical in our daily lives it was said that one day was not enough for the issue.

It is to be mentioned that the workshop was only an introduction to some of the topics used in working with conflict workshop in order to enhance our concepts of conflict and conflict analysis. 
Afghan Women Network (AWN), ACBAR Women Affairs Sub-committee and Cooperation for Peace and Unity (CPAU) are working together to organize and conduct a two weeks workshop on Working with Conflict for men and women staff of NGOs in Peshawar, in the near future.

It was suggested that training of trainers workshop be conducted for the members of AWN who could then expand the skills of conflict management to a larger community of Afghan women.

\section{Working Groups:}

The draft job description for the Working Group Members and Team Leaders were distributed. The participants worked with their group members to discuss the job description and select their Team Leaders. However, since some of the members were not present, the final decision was left for the next meeting. Members were asked to study the job description and add their comments to be discussed at the next meeting.

\section{General Rules of AWN:}

A paper in this regard was distributed to the participants for their comments and suggestions.

The Chairperson noted down their comments. Once it is approved by the executive committee of the network it would be announced in the next meeting.

\section{Chairperson \& Date for the next meeting:}

Ms Zarghoona Azimi from MARUF was volunteer to chair the next meeting which will be held on 18 November 97 at the ACBAR conference room.

\section{Any Other Business:}

The Chairperson briefed the participants on a meeting with Ms. Humaira Etemadi from the International NGO Working Group on Refugee Women, Geneva, who had visited Peshawar recently on a mission called "Chadar Solha". The papers containing information about the above mentioned NGO and "Chadar Solha" were distributed to participants. They were asked to read the materials and share their comments at the next meeting of AWN.

Ms Ofelia Bornay WFP Advisor from Islamabad announced that as a representative of WFP which is a donor agency, would like to talk to the women group and particularly those who are associated with WFP and discuss their project proposals and problems if any. This was carried out after the meeting. 


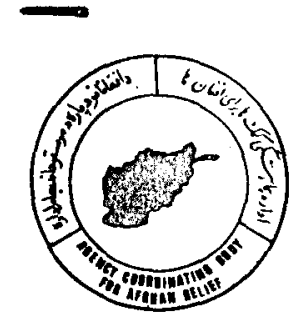

\section{Women Affairs Sub- Committee Meeting 10:00 am, 18 November 1997}

$\begin{array}{lll}\text { Chairperson: } & \text { Zarghuna Azimi } & \text { MARUF } \\ \text { Minutes: } & \text { Belquis } & \text { ACBAR } \\ \text { Participants: } & & \end{array}$

\begin{tabular}{|c|c|c|c|}
\hline Adela & AREA & Malalai & Khadija Kubra School \\
\hline Diaña Ibrahimi & $\mathrm{ANCB}$ & Masooda & AGHCO \\
\hline Diana Poya & ACBAR & Najiba & Takharistan School \\
\hline Dr. Nasrin & $\mathrm{HCl}$ & Nasreen & VSB \\
\hline Eng. Aqila & AWDP & Nazifa & AIL \\
\hline Eveline & UNOCHA & Nelofar & AMRAN \\
\hline Fawzia & CARE & Partawmina & AWRC \\
\hline Nelofar & AMRAN & Qamar & Fatima-Zahra School \\
\hline Fukhraj & Afghanaid & Sadozai & WDPA \\
\hline Hadia & UNOCHA & Salima & IRC \\
\hline Hamida Anwari & ICC. & Shenky & $\mathrm{CCA}$ \\
\hline Hellai Popal & BEFARe & Sohaila & S.A Belgium \\
\hline Homa Zaafer. & ROAOW & Sohaila & RSSA \\
\hline Iris & UNHCR & Taiba Sohaila & $\mathrm{BBC}$ \\
\hline Jamila Akbarzai & AWWD & Zarghuna Baqie & IRC \\
\hline Khairia & WUR & & \\
\hline
\end{tabular}

\section{Approval of the agenda and minutes of the last meeting}

Both the agenda and minutes were approved without comment.

\section{Job description of the working groups}

As agreed at the last meeting, it was expected that members come with their comments and suggestions on the drafted job description which was prepared by the Executive Committee of the Network.

There were no changes recommended, the job'description of the working groups were approved.

The working groups will meet in the following days to work on the action plan for the year 1998 :

\begin{tabular}{|c|c|c|c|}
\hline Date/Time & Working Group & Venue & Members \\
\hline Thur, 20 Nov. $10: 00$ & Health & $\mathrm{HCI}$ & $\begin{array}{l}\text { - Masooda Omar } \\
\text { - Dr. Nasrin } \\
\text { - Dr. Zobaida } \\
\text { - Belquis } \\
\end{array}$ \\
\hline Mon, 24 Nov. $10: 00$ & $\begin{array}{c}\text { Child Rights } \\
\text { - }\end{array}$ & MARUF & $\begin{array}{l}\text { - Palwasha } \\
\text { - Tahera Ihrari } \\
\text { - Breshna Mangal } \\
\text { - Afifa Azim } \\
\text { - Nabila Haqbeen } \\
\text { - Zarghuna Azimi } \\
\text { - Nazefa Abedi } \\
\text { - Belquis }\end{array}$ \\
\hline
\end{tabular}




\begin{tabular}{|c|c|c|c|}
\hline Date/Time & Working Group & Venue & Members \\
\hline Mon, 24 Nov. $14: 00$ & Information & WDPA & $\begin{array}{l}\text { - Sadozai } \\
\text { - Jamila Akbarzai } \\
\text { - Sohaila (RSSA) } \\
\text { - Farida (WCSP) } \\
\text { - Eveline } \\
\text { - Belquis }\end{array}$ \\
\hline Tues, 25 Nov. 10:00 & Training & AWRC & $\begin{array}{l}\text { - Afifa Azim } \\
\text { - Farangis } \\
\text { - Mehria } \\
\text { - Partawmina } \\
\text { - Noorzia } \\
\text { - Farida Azizi } \\
\text { - Lena } \\
\text { - Belquis }\end{array}$ \\
\hline Wed, 26 Nov. $10: 00$ & Women Rights & ACBAR & $\begin{array}{l}\text { - Najiba } \\
\text { - Sohaila Yarzad } \\
\text { - Eng. Aqila } \\
\text { - Hamida Anwari } \\
\text { - Belquis } \\
\end{array}$ \\
\hline Wed, 26 Nov. 14:00 & Cultural & $\mathrm{BBC}$ & $\begin{array}{l}\text { - Homa } \\
\text { - Taiba } \\
\text { - Laila Sarahat } \\
\text { - Belquis }\end{array}$ \\
\hline Thur, 27 Nov. 14:00 & Education & ANCB & $\begin{array}{l}\text { - Fawzia } \\
\text { - Khorshid } \\
\text { - Hawa Majid } \\
\text { - Adela } \\
\text { - Qudsia } \\
\text { - Hadia } \\
\text { - Diana Ibrahimi } \\
\text { - Nasrin } \\
\text { - Malalai } \\
\text { - Belquis }\end{array}$ \\
\hline
\end{tabular}

\section{Chadar Solha}

Any comments on this issue should be addressed to Safia in DACAAR, Palwasha in IRFAN Centre and Shenky in CCA office.

\section{HCI, activities}

Dr. Nasrin from Human Concern International ( $\mathrm{HCI})$, briefed the floor on the background and activities of $\mathrm{HCl}$. The organisation started operations for Afghan refugees and Afghanistan in 1980. Sectors of operation covered are Preventative health care, Income generation programmes, Vocational training, Education, Engineering and Agriculture.

$\mathrm{HCl}$ has conducted the following activities in Pakistan and inside Afghanistan:

- Emergency feeding and winter clothes to displaced families in Kabul and surrounding areas.

- Mobile clinic services to displaced people from Kabul and surrounding areas.

- Khost airport repair, runway and checkposts. 
$\mathrm{HCl}$ is planning a vocational training and income generation programme for widows in Kabul.

In Pakistan, under the name of Hope Village, this organisation provides training for some 450 students. In its $\mathrm{MCH}$ clinics for Afghan refugees in Akora Khatak camp, $\mathrm{HCI}$ also provides family planning training and health care training. Dr. Nasrin pointed out that health services need to be expanded particularly in Akora Khatak Camp. Interested agencies are requested to contact $\mathrm{HCl}$ office for further information regarding the situation in this camp.

Iris from UNHCR, promised to visit the camp in the near future and see what UNHCR can do about it.

\section{Any other business}

Partawmina suggested that those of us who have information on educated Afghan women who beg on the streets of Peshawar or who are in dehumanizing positions, are requested to introduce those women to the Executive Committee of the Network. The network is not in position to support them financially, however, they will try to find solutions and give them moral support, indications of where to seek employment and give them free consultations.

- Ms. Homa stated that Afghan women should feel the responsibility to support the Afghan community particularly women by teaching them and making them aware of the possible ways of how to improve their lives. This would include teaching on the awareness of basic human needs and human rights. Women should always condemn differnt types of discrimination and violence against women and girls in families and in community and address the importance of women's role in development and rehabilitation of Afghanistan.

- Ms. Aqila from AWDP, recently returned from Kabul, briefed the participants on the economic situation of Kabuli women. She emphasised the need for income generation projects in Kabul in order to help their economic situation.

- 16 days of Activism against Gender Violence, Nov. 25-Dec. 10, have been announced by the Centre for Women's Global Leadership at Rutgers University. November 25 is International Day against Violence against Women, declared in 1981 in Bogota. AWN will celebrate this day by conducting a seminar on Domestic Violence and will also consider holding an exhibition of Afghan women's embroidery and handicrafts on 27 November. Those interested in participating in the exhibition are requested to contact Partawmina in AWRC or Homa in ROAOW offices.

- Iris, the Protection Officer from UNHCR, asked the contact address of participants and they were also asked to contact her in case they meet any women who have security problems.

- The participants suggested that a letter highlighting the plight of the refugee women, be sent to Alfredo Witschi-Cestari and Ms. Angela King and donor agencies. The letter should explain the situation of these refugees, particularly educated women in Pakistan who have been neglected since 1992. The letter should contain a paragraph about various types of violation of women's human rights in refugee camps including harassment by Pakistani soldiers.

\section{Date and Chairperson for the next meeting}

Ms. Sohaila Yarzad from SAS. Belgium, will chair the next meeting, which will take place on 16 December 1997 at the ACBAR office. 


\section{Women's Affairs Meeting \\ January 14, 1996 \\ 10:00 am at ACBAR Office}

Chairperson:

Khorshid Noori

$N A C$

Participants:

Rahima
Terina
Freshta
Shalah
Aqila
Noor Zia
Sohnila
Farida
Dr. Zobaida Popal
Partawmina
Dr. Noorjan
Safia Siddiqi
Mahboba Hoqoqmal
Afifa
Malalai
Belquis R.A.

AMRAN

$C C A$

$C C A$

$C C A$

$A W D P$

CoAR

ASYAR (SAB)

$N C A$

$D C A$

$A W R C$

$A W R C$

I) $A C A A R$

AMRAN

Radda Barnen

$A C D O$

$A C B A R$

Agenda:

Approval of the agenda and minutes of the last meeting:

Activities of the working groups:

Name and symbol for AWN newsletter:

Activity update (by agencies):

Any other business.

Approval of minutes of the last meeting

The minutes of the last meeting and the agenda were approved

Activities of the working groups;

The activities of the groups were described as follow:

\section{Cultural Working Group}

This group will be responsible for publishing the AWN newsletter. Their activitics will include printing. providing matcrials, etc

To publish the first edition. the Cultural group requested the members of the network for contribution.

\section{Health}

The working group will be responsible to collect information on health situation within Afghan women refugees in camps.

They will also identify the needs of people from the health aspect such as dia training. health cducation.. etc. 


\section{Foreign Relations}

This group will establish and maintain contacts with other women networks in Pakistan. Afghanistan and other countries.

\section{Social Affairs}

Members of this group will be responsible to identify the main problems concerning the Afghan women. and will work on solutions. i.e. provision of education. health. employment. etc.

\section{Name and symbol for the AWN newsletter;}

After some discussion. the name of the newsletter was sclected to be DAWN. and a earth globe. with picture of an Afghan woman loolding her baby in her arms and a book in her hand inside the globe. will be the symbol of the newsletter.

\section{Activity update:}

Participants were asked to send a copy of their monthly women related activities to the Women Affairs Program Officer, ACBAR.

\section{Any other business:}

* It was suggested that 'amnouncements' should be included in the agenda.

* Safia Siddiqi's first book (THE UNREADED BOOK), bas been published recently. She was congratulated for this. To celebrate this, a party will be conducted on 28 . Jcer. in Islamabad.

* The floor decided that if the people invited to the meetings do not attend three consecutive meetings. their names will be removed from the mailing list.

Some changes were brought in the members of the groups.

Cultural

\begin{tabular}{|l|l|l|l|}
\hline$\#$ & Name & Igency & Phone \\
\hline 1 & Maliboba Hoqogimal & AMRAN & 845446 \\
\hline 2 & Noorzia & CoAR & 41188 \\
\hline 3 & Safia & DACAAR & 43245 \\
\hline 4 & Khorshid & NAC & 43717 \\
\hline 5 & Fawzia & AWC & 812115 \\
\hline 6 & Lecna & NCA & 840304 \\
\hline 7 & A & 841552 \\
\hline 8 & Partawmina & AWRe & 841552 \\
\hline
\end{tabular}

Health

\begin{tabular}{|l|l|l|l|}
\hline$\#$ & Name & Agency & Phone \\
\hline 1 & Dr. Zobaida & DCA & 44731 \\
\hline 2 & Dr. Shamslad & DCA & 44731 \\
\hline 3 & Dr. Malalai & SCA & 814772 \\
\hline 4 & Razia & DACAAR & 43245 \\
\hline 5 & Sharifa & DACAAR & 43245 \\
\hline 6 & Dr. Noorjan & AWRC & 841452 \\
\hline
\end{tabular}

Foreign Relations

\begin{tabular}{|l|l|l|l|}
\hline$\#$ & Name & Agency & Phone \\
\hline 1 & Melria & ATC & 40412 \\
\hline 2 & Safia & DACAAR & 43245 \\
\hline 3 & Belquis & ACBAR & $44392 / 40839 / 45316$ \\
\hline 4 & Mahboba Hoqogmal & AMRAN & $845+46$ \\
\hline 5 & Rahela & WFP & $2736+1$ \\
\hline 6 & Farida & NCA & 840340 \\
\hline
\end{tabular}


Social Affairs

\begin{tabular}{|l|l|l|l|}
\hline 11 & Name & Agency & Phone \\
\hline 1 & AAssoda_Fariha & AGHCO & 846491 \\
\hline 2 & Sohaila & SOS-PG & 812456 \\
\hline 3 & Amena Bower C & MARUF & 44986 \\
\hline 4 & Aqela & AWDP & \\
\hline 5 & Hajera Quchria & AWDD & \\
\hline 6 & Malalai & ACDC & 818188 \\
\hline 7 & Freshta & CCA & 810116 \\
\hline 8 & Terina & SCA & 810116 \\
\hline 9 & Nasrin AGiGer & VSP & 893618 \\
\hline 11 & Shfia & AWRC & 841552 \\
\hline$H$ & CCA & 810116 \\
\hline
\end{tabular}

\section{NEXT MEETING}

Ms. Mahboba Hoqoqmal from AMRAN will chair the next Women Affairs meeting, which would be held on 26, February, 1997 at the ACBAR conference room. Agendal will be sendl later on. 


\section{Agency Coordinating Body For Afghan Relief Women Meeting Held on March 19, 1996 By: Shenky Zahery}

\section{PROMINENT ISSUE: (WIDOWS/IDSAIBIEI) WOMEN ANI) ORPHANS)}

Shenky welcomed the participants and hoped that the meeting will focus on vulnerable issues and suitable solutions will be allained.

i. Approval of Minules of the l,ast Mecling:

Minutes were approved.

ii. Ammouncements:

AWRC announced that they have completed a one week advocacy program to beggar women in Peshawar city. About 100 beggar women participated in this program. The women were mostly widows or their husbands were disabled. They expressed that they will no more continue beggary if a comprehensive program is established to involve them.

iii. Widlows, Disabled Women and Orphans Programs:

a) Identify General Problems

ROAOW reported that the conclusion of their survey in Jalalabad and Kandahar showed that widows are the most vulnerable group, since they are mostly deprived of working facilities, while having no income source.

It was suggested that agencies should conduct income generation programs, such as tailoring, soap making etc, thence the women and their families will be provided with a minimum sustenance.

AWWD believed that financial problems have caused a big number of women to start begging. This is a serious issue and should be urgently addressed through launching income generation projects. 
Zarghona Ana High School raised the education problem of orphans, stressing that they should be provided financial contribution, beside school fee, by their relevant schools. The representative of Zarghona $\Lambda$ na School provided an example of her school. where 180 orphans study and they are badly in need of assistance.

$\triangle C B A R$ stated that instead of cash support, provision of stationary and other needs of students will further support the process of education.

$\Lambda$ social worker of Nasir Bagh refugee camp, who participated in the meeting, raised the main problems of refugees in the camp; there are a big number of illiterate women. who do not have other skills either, to ensure an income.

The orphan school in Nasir Bagh Camp has not received any assistance so far.

$\Lambda W C$, with regards to the Nasir Bagh Orphans School, saicl that they intended to extend assistance to this school but the number of students was mentioned far more than the actual figure. It was requested to provide accurate statistics to be considered for assistance.

UNDCP use to support blind women, but this project has discontinued. This group is considered as the most helpless, thus ways should be sought to assist them.

\section{b) Identify General Needs}

It was totally believed that income generation programs for women should be accelerated and further strengthened, that could ease the burden of sustenance making for women. Special projects should be intended to discourage begging among vulnerable women and to provide them with suitable financial substitute.

ACBAR denoted that orphan schools should directly contact IRC and ask for assistance.

It was suggested that some of the big cloth markets should be contacted and skilled women should be directed to refer to the markets for work. Mostly, in such type of works, the women are unfairly paid. This issue should also be raised with the cloth dealers in the markets.

Members of the meeting were of the vicw that a fund should be initiated by individual Afghans donations. The fund could be used for implementation of a big project, with widows and orphans as target groups.

\section{c) Viable Training Programs}

Basically, very is done for widows and orplians currently. There are some training programs in the camps as well as cross border, especially in Jalalabad, but they are inadequate. 
NPO/RRA has a loan program lor women. Around 300 women have laken loans within this program. Loan would alve to be repaid in one year.

\section{d) ISRA Program}

It was reported that ISR $\Lambda$ has closed a big part of their programs for women refugees in the camps. It was said that the rest small part of ISR $\Lambda$ 's activities should be foctused on urgent needs and vulncrable targets.

\section{iv. Any Other Business:}

The $\Lambda$ WDG also discussed a suggestion that a workshop be held, by $\Lambda C B \Lambda R$, and women, especially widows, inviled to attend. The women will be given the opportunity to express their necds and views accordingly.. $\triangle \mathrm{CB} \wedge \mathrm{R}$ will lake this point and the possibilities into consideration.

\section{Participants:}

\begin{tabular}{|c|c|}
\hline Rahila & WFP \\
\hline Shayema Wali & SlelRVIE \\
\hline Freshta & SIIRVI: \\
\hline Mariam & ROWAO \\
\hline Huma & ROWAO \\
\hline Shayena Kamali & Zarghona Ana School \\
\hline Zakia & Animator Nasir Bagh Camip \\
\hline Hafifa Azam & RBTU \\
\hline Faiza Zara & UN/OPS \\
\hline Maliha Danish & UNDCP \\
\hline Hawa Majid & SCA \\
\hline Malaly & SCA \\
\hline Halima & Bakhtar School \\
\hline Lisa O. Prois & BEFARe \\
\hline Fariha & NPO/RR $\Lambda A$ \\
\hline Qadria & NPO/RRAA \\
\hline \multicolumn{2}{|l|}{ Nazifa } \\
\hline Jamila $\Lambda$ kbarzai & AWWI \\
\hline Fawzia & $\Lambda W C$ \\
\hline Najia Qurieshi & $\triangle W R C$ \\
\hline Shenky Zahery & $\triangle C B A R$ \\
\hline
\end{tabular}




\section{Women's Affairs Meeting \\ November 12, 1996 \\ 10:00 am}

Chairperson:

Belquis R.A.

ACBAR

Participants:

Safia Seddiqi
Dr. Malali
Nasreen
Rahima
Fariha
Qadria
Nooria Saidi
Eng Rahila
Farida Sediqi
Ghezala Aslam
Spogmie
Zubaida
Shamshad
Liz

DACAAR

$S C A$

VSB

AMRAN

NPO/RRAA

NPORRAA

Canada Fund

WFP

NOWE

NOWE

$A W C$

$D C A$

$D C A$

ACBAR

The meeting started at 10:15 am at the ACBAR office.

Agenda:

Introduction of the participants;

Presentation of the Peshawar network;

Past activities;

What is ongoing and going to be done;

Election of the chairperson for the next meeting;

Any other business;

- Introduction of the participants

The above participants introduced themselves

* Presentation of the Peshawar Women Network;

The Network has been established in April 1996 and has 32 members now.

The objective of the network is to conduct training workshops ie capacity building, leadership; and to raise women right issue within community.

Later the Women Advisory group was established and' 12 people were identified as members including men and women working for different agencies.

* Past activities;

Since January 1996 five workshops have been conducted on various topics.

What is ongoing and going to be done;

This issue will be discussed at the next meeting

Election of the chairperson for the next meeting;

Ms. Safia Seddiqi from DACAAR was elected to preside over the next meeting.

The next meeting will be held on December 10, at 10:00 am at the ACBAR office.

Agenda for the next meeting will be circulated later.

* Any other business;

- ACBAR was requested to provide a list of agencies involved in carpet weaving for Afghan refugees. 
- It was decided that members of the network should be those who are in direct contact with women in the communities.

- Constitution for the women network should be prepared. All members were asked to draft a constitution individually and bring it to the next meeting. One constitution from the various papers prepared by each individual will be made.

- The problems of the very poor Afghan women were discussed. This issue will be further discussed at the next meeting.

- It was suggested that men and some Pakistani sisters be invited to the meetings in the future for information sharing purposes.

- Ms. Ghezala from NOWE briefed the floor on their organization's current activities (Altach please find a copy of the report)

- Participants were asked to submit a report on activities for women (monthly, annually) to the ACBAR ofrice for recording purposes.

\section{Announcement}

Follow up workshop (Proposal Writing) will take place on November 28 in the ACBAR office. 


\section{Women's Affairs Meeting December 10, 1996 \\ 10:00 am}

Chairperson:

Participants:
Safia Seddiqi

Hajera

Mehria

Aqila

Noor Zia

Leena

Masooda Omar

Nasreen

Anina Bawer

Dr. Zobaida Popal

Dr. Shamshad Quraishi

Khorshid Noori

Sohaila

Mahboba Hoqoqmal

Belquis R.A.
DACAAR

AWDD

ATC

$A W D P$

CoAR

$N C A$

$A G H C O$

VSB

MARUF

$D C A$

$D C A$

$N A C$

SOS-PG

AMRAN

$A C B A R$

The meeting started at 10:00 am at the ACBAR ollice.

Agenda:

Approval of the minutes of the last meeting;

Brief information on proposal writing workshop;

Topics to be covered in 'human rights workshop;

Discussion on goals and objectives of AWN;

Activity update;

Any other business;

Auproval of tlic minutes of the last mecting

The minutes were approved.

Brief information on proposal writing workshopl

The floor was briefed on the results of the workshop, as some of the participants were not present at the workshop.

Belquis from ACBAR was asked to send a copy of the proposal to the participants of the meeting, which could be used for future proposal writing purposes.

Topics to be covered in 'human rights workshop

A workshop 'on human rights and child rights' is going to take place on human rights issue in February. The exact date will be announced later.

\section{Discussion on goals and objectives of AWN}

The goals of the network 'were once again specified as follows:

To make sure women's basic human rights are included in all interim peace agreements. These rights are:

-The right to employment outside home.

-The right to security. Women should not be harassed or forced to wear uniform clothing.

-The right of women and girls to equal access to education.

-The right of women to be trained in leadership, advocacy and networking skills.

-To increase their access to information about struggling for peace and human rights throughout the world. 


\section{Activity update}

In order to have a source of record on women's activities, agencies were asked to submit their women activity reports to ACBAR Program Officer Women Affairs as soon as possible.

\section{Any other business}

It was said that the network should have a newsletter with a symbol. Therefore, the participants were asked to work on this issue.

For the easy implementation of the objectives of the network, the following four groups were formed:

Cultural

\begin{tabular}{|c|l|l|l|}
\hline$\#$ & Name & Agency & Phone \\
\hline 1 & Mahboboa Hoqoqmal & AMRAN & 845446 \\
\hline 2 & Noorzia & CoAR & 41188 \\
\hline 3 & Safia & DACAAR & 43245 \\
\hline 4 & Khorshid & NAC & 43717 \\
\hline 5 & Fawzia & AWC & \\
\hline 6 & Leena & NCA & 840304 \\
\hline
\end{tabular}

\section{Health}

\begin{tabular}{|l|l|l|l|}
\hline$\#$ & Name & Agency & Phone \\
\hline 1 & Dr. Zobaida & DCA & 44731 \\
\hline 2 & Dr. Shamshad & DCA & 44731 \\
\hline 3 & Dr. Malalai & SCA & \\
\hline 4 & Razia & DACAAR & 43245 \\
\hline 5 & Sharifa & DACAAR & 43245 \\
\hline 6 & Dr. Noorjan & AWRC & \\
\hline
\end{tabular}

Forcign Relations

\begin{tabular}{|c|l|l|l|}
\hline$\#$ & Name & Agency & Phone \\
\hline 1 & Mehria & ATC & 40412 \\
\hline 2 & Safia & DACAAR & 43245 \\
\hline 3 & Belquis & ACBAR & $44392 / 40839 / 45316$ \\
\hline 4 & Mahboba Hoqoqmal & AMRAN & \\
\hline 5 & Rahela & WFP & \\
\hline
\end{tabular}

\section{Social Affairs}

\begin{tabular}{|l|l|l|l|}
\hline$\#$ & Name & Agency & Phone \\
\hline 1 & Massoda & AGHCO & 846491 \\
\hline 2 & Sohaila & SOS-PG & 812456 \\
\hline 3 & Amena Bower & MARUF & 44986 \\
\hline 4 & Aqela & AWDP & \\
\hline 5 & Hajera & AWDD & \\
\hline 6 & Malalai & ACDC & 818188 \\
\hline 7 & Freshta & CCA & \\
\hline 8 & Trina & & \\
\hline 9 & Nasrin & VSB & 893618 \\
\hline
\end{tabular}

\section{NEXT MEETING}

Ms. Khorshid Noori form NAC will chair the next Women Affairs meeting, which would be held on 14, January 1997 at the ACBAR conference room. 


\section{ACBAR \\ MINUTES OF TILE \\ AFGHAN WOMEN'S EDUCATION MEETING \\ 26 SEPTEMBER 1995 \\ By: Shenky Zahery}

The meeting started with a welcome speech by Shanky zahery. She introduced the agenda for the meeting.

Following individual self-introduction, the participants detailed about their programs ongoing. Educational problems were discussed.

\section{Malalay Iigh School:}

This school is facing no major problem at the time being, wile certain problems constantly exist. Representative of the school considered a prevajling problem among the schools community in Peshawar; very few of the school rumers know little about the essential educational rules and methods. Schoois and school runners are mostly business oriented. School managers are greatly concerned on attracting more students, with low consideration of merit and educational level.

In response to a question, she clarified that French minjstiy of Education is financially supporting Malalay High School, as il: did in past, when the school was based in kabul.

\section{Zarghona Ana lligh School:}

This school was established in 1986, and since then SCA supported it to 1993. From 1993 on till now this school has received I Fe. support. The limited allocation from IRC pooxly suffice tre salaries, while other expenses stand apart; thus to maintain the expenses the school has to charge the students with school fee.

The representative of Zarghona Ana High School expressed hr defp concern over financial status of most of the students who live in refugee camps and definitely. cannot afford paying school fee. She suggested that, iricase we get 4 or 5 students from one family, all of them should have to pay for school fee.

She was satisfied with the meeting and appreciated the role of ACBAR in holding such meetings, that help in resolution of problems .

\section{Sultana Razia School:}

This school has been functioning for seven years in Pakistan. After the interim government moved into Afghanistan, it closed 
down; but later, with cooperation of ACBAR women Affairs, the school was; able to get funds fixom IRC.

Representative of Sultana Razia School reported that IRC has stop funding; presently the school is facing critical situation, having no fund on hand to cover house rent, teacher salaries, stationary and other materials. If the school does not receive fund from any source, cl ssage is feared.

\section{Ome-Somia School:}

This school is also stuck with a series of problems, e.g. house rent, teacher salaries, tsaching materials, etc. This school is functioning from $6: 30$ am :0 5:30 pin every day.

She requested the donors :0 properly support schools and modify their policies in this re ard positively. She believed that some donors support primary sch ols; however, when primary schools are developed to high schor is they cut or reduce funding. She was of the opinion that schiol is a battle field against ignorance and base of progress. School support should be given priority.

\section{Bibi Hajar High School:}

This school comprises 1000 students and is supported by women Islamic Party in Hayatabad. "epresentative of Bibi Hajar High School explained that they pt. ride primary and higher education for Afghan girls, and students are chargau no schuol fee.

\section{Bakhtar Primary School:}

This school is established in 1994. No source has so far funded the school! The representative stat: d that they had referred to BEFARe and Afghan Commissionarate fox support; the first refused while the second proceed to a gurvey; 1, evertheless, the survey result and any consequent assistance is not known yet.

She forwarded a request through ACBAR to funding bodies, to take care of the problems faced by their school. She hoped that ACBAR meeting for women affairs will prove helpful.

\section{Fatemat-ul-Zahra High School:}

Established in 1986 with initiatives and funding by an Islamic Party. In 1991, as the Islamic Party support stopped, University of Nebraska funded the school, and from 1992 on IRC has been financially supporting Fatemat-ul- Zahra High School. Unfortunately, IRC has reduce teacher salaries to $50 \%$ since June, 1995. The lacquired fund from IRC poorly covers the needs.

Representative of Fatemat-ul- Zahra High School believed that dealing with economical problems is beyond the might of 
individual schools, thus joint attempts should be made. She stressed on the role of ACBAR respectively. She also wished that funding soprces. will get interagted in their problems and help the school sustain.

A school representative mentioned about IRC's letter to their school notifying that IRC: will provide only $50 \%$ of teacher salaries for the coming academic year. IRC implies towards charging fee to cover the rest of salaries and school expenditure. She believed that all students are not able to pay for school fee, therefore, IRC is requested to fully support the school.

ACBAR representative clarified that based complains from some school teachers and principles about reduction of salaries, she talked to IRC\FETTP, and was told that, except for one school, there has been no change in TRC policy for teacher salaries. Although she tried to find a copy of IRC's letter, sent to the schools, to find out the exar.t issue but the schools did not provide her with a copy.

\section{$\Lambda W C:$}

AWC has been functioning for $9 y$ ciars. It carries on activities in different fields e.g. school, clinic, hospital, etc. There is no particular permanent funding solrce to this organization. Representative of AWC was happy to attend ACBAR meeting and hoped that they would come up with good rissults. She requested ACBAR to follow up their problems with colcerned authorities.

RBTU supported the idea to fix a school fee; "families should have some responsibilities too" she xensoned, but limitations should be observed, i.e. all students :hould not be charged and students should be differentiated according their economical status. She proposed to hold a gathering of parents and discuss the problem. It will help to take their financial status in consideration.

She stressed that parent's should be expected to contribute as much as their financial situation permits. Parents should reduce educational problems faced by their children.

AWWD was concerned about the fee fixing isrle. The representative said that most families would stop sending their children to school if they are asked for school fee. She suggested that the issue should be carefully dealt with, and minimum fee should be fixèd. 
AWRC expressed deep concern over the living circumstances of Afghans. The problems should be identified and people should be helped. Foor living conditions do not permit the people to uhint: of educational facilities.

An idea was presented to the floor that members of the meeting, who run educational programs for women, have a meeting with Director of UNHCR and Afghan Commissionarate. The idea was overally supported. Then, it was decided that:

ACBAR should send minutes of the meeting to Director of UNHCR and Afghan Commissionarate.

ACBAR Programme officer Women Affairs, should make appointment with UNHCR and Afqhan Commissionarate, and lix a date for meeting.

ACBAR should make the arrangements for the meeting and inform all women education programmes.

- Minutes of the meeting should also be sent to embassies and other authorities, involved in assisting educational programmes for women.

\section{Any Other Business:}

The floor favored to pray for late Sultana, ex-principle of Sultana Razia, who has passed away.

\section{Participants of the meeting:}

$\begin{array}{ll}\text { Hafifa Azim } & \text { RBTU } \\ \text { Muslima Waziri } & \text { NRC/NCA } \\ \text { Jamila Wahidi } & \text { Bibi Hajar ltigh School } \\ \text { Mariam Ihsanyar } & \text { AWRC } \\ \text { Parveen Arafi } & \text { AWRC } \\ \text { Shah Bibi Halimi } & \text { AWRC } \\ \text { Najia Zewari } & \text { AWRC } \\ \text { Halima } & \text { Bakhtar Prim.ry School } \\ \text { Hafiza Raufi } & \text { Bakhtar Primary School } \\ \text { Zubiada } & \text { Sultana RazizHigh School } \\ \text { Laila } & \text { Sultana Raziz High School } \\ \text { Fatana Gillani } & \text { AWC } \\ \text { Rahima Safi } & \text { AWC } \\ \text { Shaheen Parveen } & \text { UNHCR } \\ \text { Qumar Jan } & \text { Fatemat-ul-Zahra School } \\ \text { Shayema Kamali } & \text { Zarghona Ana School } \\ \text { Khadija Raufi } & \text { Malalay High School } \\ \text { Jamila Akbar Zie } & \text { AWWD . } \\ \text { Khurshid Noori } & \text { NAC } \\ \text { Hamida Anwari } & \text { AVICEN } \\ \text { Noor Jahan } & \text { AWWD } \\ \text { Shenky Zahery } & \text { ACBAR } \\ & \end{array}$




\section{MINUTSS OF THE MEETING OF \\ AFGHANI WOUEN'S DISCUSSION GROUP \\ THURSDAY 18 AUGUST 1994}

At the beginning of the meeting participant introduced themselves and approved the minutes of last meeting.

Participants explained the activities of their offices as follows.

DCA - Narisa and Zabiada

DCA has started poultry training program in Nasir Bagh camp. This course cover cne week. ard at the end of the course some kit are qiven to the trainees.

UMCA -. Masuma Raza

UNCA has Dia. Training program. About 220 women have been trained in Nasix Bagh camp. At the end of the course UMCA gives certificates and Dia kit to the trainees.

SCF U:K - Sima and Sahar.

SCF U.K has health actirities. About 2000 women has been trained j.m FiWP and 5000 as Community Health Workers, so far SCF run an MCH clinic in Nasir Bagh camp.

They had literacy program for men from 1988 to 1.993 , and have started women's literacy program in 1993.

- Dr. Jamila from Afghan Women's Council and Fowzia from Aryana primary school.

Afghan Women's Council has Mother and Child Health Program, School, Sewing Center and course for teaching Quran and English.

FEP/IRC - Hamida Zia and Mariam Fariwar

FEP has training of literacy, Islamic studies and Education (supports 25 schools in different camps).

AWRC - Parween Arifi and Nasreen Akhtari

ANRC has trained about 300 women in litexacy training program (one week course). At the end of each course a kit of medicine alid some equipinent are distributed to the graduated trainees. rraining of 400 women in Knitting and teaching of Quran is in the future plan of AWRC.

SC. U.S - Saljma Ali Hatimi/ Spozmie Noori Ahmad/Shafiqa Ali and vatifa Ershad.

SC U.S. has Ilealth, Jiteracy, and Handicraft programs. Credit sacheme/self reljance program started recently. 
APA - Zakia
APA has started irrigation, agriculture and distribution of materials to orphans, widows, displaced and needy people in Paktia, Wardak, Nangarhar, Parwan, Kabul, Laghman and Paktika provinces since 1989.

Recently a new department for women was created. The main purpose of this department is to make needy and poor families self reliant, and pave the way for their participation in reconstruction of Afghanistan. This deportment will have poultry, Honey bees keeping, literacy, kitchen gardening, and growing of non fruit trees sapling programs in above mentioned provinces.

NAC - Khurshid Noori Sawize

NAC had 42 schools which had only three classes for girls at the beginning. At present NAC has two high schools and six primary schools in Ghazni province.

The previous NAC activities which were in Iran have shifted to Herat province of Afghanistan.

AWWD - Jamila Akbar Zaie from

AWWD has been started literacy, Islamic studies and Health training programs since 1990. Teaching and Learning programs, primary and higher programs of computer has been started in 1993, and a very new program of WP/60 started recently. Soap and candle making is the main interest of women in the camps. The future plan of the office is to start candy making program in the refugees camp.

\section{Manifesto of AWDG}

Before the formation of manifesto, formation of platform is very important. For this purpose Shenky Zahery will call a committee and will work on platform of AWDG.

It was suggested that not only the educated working women should be invited to these meetings, the uneducated women who are very active also should be invited to the meeting and conferences. It was decided that these uneducated women will only be

participating at the meetings and share the ideas, not to act as a member of advisory' board or AWDG.

Shenky Zahery and Khurshid Noori will select the members of the committee, and it was decided that the advisory board should be selected in next meeting: 
Development of Education Through Schools, Nurseries and Anti Iliteracy.

Discussion was made about the development of education through the schools, Nurseries and anti illiteracy combat. It was agreed that the creation of such programs and courses in the immigration status is very necessary and helpful for the Afghan women

Past experiences show that most of the families are against the girls education, but this problem has been solved a little after a long discussion with them. As we know that because of economical problems it is the expectation of the families to get some financial help or assist from any sources.

It was proposed that more efforts should be put to acknowledge of the people the virtual values of the matters than its material values in order to make the people self reliant. It will be ideal if such programs be arranged inside Afghanistan.

To arrange such programs and promote the virtual values, it is necessary to approach the circumstances of the surrounding environment.

The following factors also help in making the program efficient.

1. Creation of literacy program in all programs.

2. Creation of Dari and Pashto courses for the students who are studying in Pakistani schools.

3. Group leaders should be selected among the educated women from the same rural areas

4. Teachers should be selected from the previous students who got top positions.

\section{Development of loan credit. scheme:}

SC U.S Islamabad said about this was running in Haripoor and Sawabi camps. Mansera camp is the future plane of this office. The effective of this program is to make the needy and poor people self reliant.

In this program a group of(5-6 women) were paid Rs. 1000 each which should be repaid (refunded) in 12 weeks installments (12 weeks 12 installments) and a $75 \%$ of an instalment should be refunded as the 13 th instialment. This amount would be used for the expenses of the new projects. 
In future programs, it is planed that the major portion of the budged be given to bigger group of the people in order to have more income of big investments. It is the future plan to distribute the raw materials of handicraft to the needy, poor and skill women and will paid for their work. This program will be for the people who expect it, and first of all it will be given for widows, disabled and who have lost head of the family. First of all the families should find market for themselves. The groups who return their loan on time they will be selected for the next program, otherwise they will be rejected from next program.

Note: Next meeting will be on Thursday 22 september 1994 at 9:00 a.m. Please send your very important: subjeots for agenda of the meeting. 